\title{
PROSOCIALAUS ELGESIO FORMAVIMASIS UNIVERSITETO LIBERALAUS UGDYMO PROCESE
}

\section{Enrika Kromerova}

Lietuvos sporto universitetas, Kaunas, Lietuva

\begin{abstract}
ANOTACIJA
Liberalusis ugdymas traktuojamas kaip viena esminių, pamatinių aukštojo mokslo realizavimo galimybių, galvojant apie ateities visuomenès žmogų, pasižymintį tvirtomis vertybinėmis nuostatomis ir prosocialiu elgesiu. Tad kyla klausimas, kaip liberalaus ugdymo procese universitete formuojasi prosocialus elgesys? Kokia liberaliojo ugdymo vertybių raiška? Minèti aspektai sudaro šio tyrimo mokslinès problemos pagrindą. Straipsnyje nagrinejjama prosocialaus elgesio samprata ir esmé, gilinamasi i liberalaus ugdymo vertybinị pagrindą, siekiant atskleisti liberalaus ugdymo, lemiančio prosocialų elgesį, galimybes universitete. Tyrimo metu remtasi R. Barnett'o (1990) liberalaus ugdymo traktuote - konservatyviaja ir radikaliąa koncepcijomis.
\end{abstract}

Raktažodžiai: liberalus ugdymas, universitetas, prosocialus elgesys, aukštasis mokslas.

\section{IVADAS}

Jau dvidešimt pirmo amžiaus pradžioje èmė augti susidomèjimas tarpusavio ryšiais, egzistuojančiais tarp visuomenès resursų ir žmogaus, tam, kad būtų ịmanoma numatyti produktyvaus ir sveiko žmogaus vystymosi strategijas arba nustatyti ši progresą lemiančius veiksnius (Brittian, Humphries, 2015). Manoma, kad tiek prosocialus, tiek antisocialus elgesys iki šiol buvo tyrinèjami nepriklausomai vienas nuo kito. Tad prieš analizuojant prosocialumo sampratą, jo reikšmę bei ugdymo svarbą ne tik jaunimui, bet ir visuomenei, akcentuotina, kad daugeli metų mokslininkai daugiau dèmesio ir pastangų skyrè stengdamiesi labiau suprasti antisocialaus elgesio priežastis ir pasekmes gyvenime (Silva, Stanton, 1996; Veenstra, 2006). Manoma, kad pagrindus prosocialaus elgesio sąvokai padèjo W. McDougall'as (1908), kurio teigimu, tai instinktyvus tèvų ,švelnių emocijų“ perdavimo savo vaikams rezultatas (Penner et al., 2004), nors pastaroji sąvoka laikui bėgant kito ir šiuo laikotarpiu yra įgavusi kiek kitokią reikšmę, ị kurią šiuo tyrimu bus gilinamasi.

Šiandien, sprendžiant kompleksinius žmogaus ugdymo(si) visą gyvenimą klausimus, reikia visą apimančios, konceptualios ugdymosi teorijos, mano J. Česnulevičienè (2000). Jos teigimu, visa apimanti teorija remiasi ne vienareikšmišku ugdymo reiškinio nagrinëjimu, o ištisa įvairių filosofija grịstų ugdymo paradigmų sistema (2000). Tad liberalusis ugdymas suprantamas kaip viena esminių, pamatinių aukštojo mokslo realizavimo galimybių, galvojant apie ateities liberalios demokratinès visuomenès žmogų (Barnet, 1990). Universitetas, remdamasis liberalizmo principu, siekia įdiegti besimokantiems fundamentines visuomenines vertybes, kurios traktuojamos kaip socialinè moralè, idealai bei moralinès ir politinès vertybès, tokios kaip pagarba aplinkiniams, tolerancija (Martusevičienè, 2015). Manoma, kad liberalusis ugdymas skatina visos visuomenès išsilavinimo įteisinimo sąvoką, o liberalioji demokratinè perspektyva siekia bendrystès ir sutarimo dèl pamatinių visuomeninių vertybių (Barnett, 1990). Autoriaus nuomone, šios vertybės yra neišvengiamos, tad jos jungia visus žmonès, ịprasminamos ịstatymuose ir pasireiškiančios žmogaus teisėmis, apimančiomis 
visuomenès moralę bei pagrindinius demokratinius principus, tokius kaip teisingumas, asmens autonomija, žodžio laisvè. Liberaliais demokratiniais principais grịstas universitetas siekia formuoti asmenybę suteikiant jai savitą identitetą, besiremianti fundamentinèmis vertybèmis, kritiniu mąstymu, kartu ir prosocialiu elgesiu. Tad kyla klausimas, kaip liberalaus ugdymo procese universitete formuojasi prosocialus elgesys? Kokia liberaliojo ugdymo vertybių raiška? Minèti aspektai sudaro šio tyrimo mokslinès problemos pagrindą. Tyrimo objektas - prosocialaus elgesio formavimasis universiteto liberalaus ugdymo procese. Šio tyrimo metu remtasi R. Barnett'o (1990) liberalaus ugdymo traktuote - konservatyviaja ir radikaliaja koncepcijomis.

\section{METODIKA}

Tyrime buvo naudotas mokslinès literatūros analizès metodas bandant pasiekti iškeltą tikslą atskleisti prosocialaus elgesio formavimąsi universiteto liberalaus ugdymo procese.

\section{TYRIMO REZULTATAI IR APTARIMAS}

Prosocialaus elgesio esmė. Prosocialų elgesị paprastai galima apibrèžti kaip savanoriškus žmogaus veiksmus siekiant padėti kitam, patenkinant jo poreikius, nesiekiant naudos ir nelaukiant nieko mainais (Carlo, 2006; Eisenberg, 2006; Veenstra, 2006; Twenge et al., 2007; Brittian, Humhries, 2015). Mokslininkų teigimu, šis elgesys neabejotinai suteikia naudą ne tik pavieniams asmenims, bendruomenems, bet ir visai visuomenei. Juk kiekvienas asmuo nori gyventi geromis socializacijos sąlygomis, kurios pagrindas - kultūra, o dauguma kultūrų, suvokdamos, kad tai gyvybiškai svarbi sistema, skatina ir net reikalauja prosocialaus elgesio iš savo piliečių. Iš esmès minèta sąvoka atsirado kaip antonimas antisocialumui, juo nesiekiama išankstinio atlygio, apdovanojimo, pastarasis yra teigiamai suprantamas ir vertinamas aplinkinių asmenų, grupių bei socialinių tinklų, be kita ko, jis didina pozityvaus abipusiškumo galimybę. Teigiama, kad pastaroji galimybè neabejotinai skatina interesų bendrystę dèl užsimezgusių socialinių, tarpasmeninių santykių, saugant ịsitraukusių žmonių ar grupių kūrybiškumą, individualumą, autonomiją ir iniciatyvumą (Attitude Determines your Altitude, 2013). Prosocialų, ị kitą asmenị orientuotą, elgesị galima traktuoti kaip neatsiejamą žmogaus gyvenimo dalį, labai svarbią vietą užimančią pripažinimo bei sėkmingų ir ilgalaikių tarpasmeninių santykių kontekste (Dunfield et al., 2011). Minètas elgesys priklauso nuo aiškaus suvokimo, kad žmogus yra bendruomenės dalis, kurioje galima tikètis paramos ir pagalbos, palaikymo bei supratimo (Twenge et al., 2007). Tad neretai, kai asmuo jaučiasi atskirtas ar vienišas, jo polinkis prosocialiai elgtis gali būti sumažèjęs arba net ir visai dingęs.

Atskleidžiant prosocialumo svarbą šių laikų žmogui ir visuomenei, svarbu aptarti kitus tyrimus šia tema. Prosocialumas buvo nagrinètas ịvairiuose kontekstuose: dékingumo (Bartlett, Desteno, 2006), religingumo (Hardy, Carlo, 2005), vaikystès (Dunfield et al., 2011), vertybių kontekste (Padilla-Walker, Nelson, 2010; Lönnqvist et al., 2013). Aptinkama nemažai tyrimų, kuriuose prosocialus elgesys nagrinètas ir paauglystės laikotarpiu (Thompson, Gullone, 2008; Johnston, Krettenauer, 2011; Paciello et al., 2013; Srivastava, 2015). Lietuvoje taip pat randame mokslinių tyrimų, kurių metu nagrinèjami prosocialaus elgesio klausimai (Lileikis, 2007; Žukauskienè, Malinauskienè, 2009; Štuopytè, 2010; Klanienė, Šmitienė, 2013; Šukys, Šukienè, 
2015). Visgi Lietuvoje ir užsienyje pasigendama tyrimų, kurie atskleistų universitetų kaip fundamentinėmis vertybėmis grịstą visapusị ugdymą teikiančių institucijų, vaidmenį formuojant prosocialų elgesį.

Apžvelgiant skyrių matyti, kad prosocialumui, kaip vidiniam asmens apsisprendimui, ịtakos turi ne vien tik auklèjimas ar motyvaciniai rodikliai, bet ir institucinis aspektas. Naujai pažvelgus ị ši reiškinị siekiamybè būtų prosocialumo raišką skatinti ne nustatytomis taisyklèmis ar primestomis normomis, bet kuriant vertybėmis ir liberaliais principais grịstą ugdymą.

Liberalaus ugdymo vertybinis pagrindas. Kaip vieną iš labiausiai savo vertybiniu pagrindu atitinkantị prosocialumo esmę galima ịvardyti liberaluji ugdymą. Anot J. Česnuliavičienès (2000), liberalaus ugdymo samprata - tai viena metodologinių nuostatų, grindžiančių ugdymo teoriją bei sudarančių sąlygas integraliai ir laisvai asmenybei ugdyti, jos pačios saviugdai. Koncepcijos įžvalgas pateikia ir J. Horbačauskienė (2011), kurios teigimu, liberalusis ugdymas - giliausias istorines šaknis turinti ir labiausiai kintanti aukštojo mokslo tradicija, kuri kildinama iš senovès Graikijos ir Romos intelektualiosios kultūros. Bandant suvokti liberalaus ugdymo esmę ir prasmę reikètų pažymėti, kad minètas ugdymas pirmiausia išreiškiamas būsimo specialisto kritinio mąstymo plètote, siekiant jo išlaisvèjimo bei išsilavinusio profesionalo, kuris gebètų mokytis ir tobulèti ne tik universitete, bet ir visą savo gyvenimą, teigia P. Jucevičienè (2003). Tam svarbūs liberaliojo ugdymo vystomi asmens gebèjimai (Horbačauskienès, 2011).

Šiame tyrime remiamasi R. Barnett'o (1990) liberalaus ugdymo traktuote - konservatyviaja ir radikaliaja koncepcijomis. Konservatyviojoje koncepcijoje kertinis žodis „laisvé“ - akcentuojama, kad kiekvienas asmuo yra laisvas, tik jam atsiskleisti turi būti sudarytos sąlygos. Anot šios koncepcijos, aukštasis mokslas yra terpè, kur studijų sistema ir studijų programos turi būti orientuotos ị asmens laisvės raišką ir ugdymą. Vadinasi, pagrindinė pedagogo pareiga yra užtikrinti, kad studijų programa kaip įmanoma mažiau kliudytų studento saviraiškai. Tuo tarpu radikaliosios koncepcijos kertinè ašis yra žodis ,išsilaisvinimas“. Čia akcentuojamos kelios kliūtys įveikimo link. Manoma, kad egzistuoja gausybè psichologinių bei socialinių barjerų, kurie nedingsta savaime, tad edukacija šioje koncepcijoje suvokiama kaip išsilaisvinimo procesas, kurio metu siekiama per reflektavimą leisti asmeniui keisti požiūrị ir ị patị save, ir ị visuomenę. Čia svarbus ne vien ugdymo turinys, tačiau ir taikomi metodai. Šios dvi koncepcijos yra neatsiejamos ir negali veikti skyriumi, nes universitete dèstomų žinių pagrindu, leidžiama studentui veikti laisvai, priimti sprendimus ir reflektuojant kritiškai analizuoti savo veiklą (Jucevičienė ir kt., 2010).

Minètų koncepcijų autorius R. Barnett'as (1990) teigia, kad universiteto liberaliojo ugdymo procese ịprasmintos pamatinès aukštojo mokslo vertybės, tokios kaip institucinè autonomija, akademinè laisvė, atviras forumas debatams, kritiškas mąstymas, mokslinis tyrimas, studentų autonomijos ugdymas ir intelektualiosios kultūros visuomenëje formavimas. Akivaizdu, kad liberalusis ugdymas remiasi prosocialų elgesi suponuojančiomis vertybėmis. Tad universitetas liberalaus ugdymo procese turi potencialą prosocialiam elgesiui formuotis, tačiau svarbus veiksnys yra ir asmens priklausomumas institucijai. Tyrimai rodo, kad stiprus asmens ištikimybės jausmas (t. y. gebėjimas gyvenime vadovautis moralinėmis vertybėmis neatsižvelgiant $i$ aplinkinių asmenų ar grupių prieštaravimus ir kritiką) gali turèti teigiamos ịtakos prosocialaus elgesio raiškai, jei tik 
žmogus jaučiasi ịsipareigojęs vienai ar kitai socialinei grupei ar ịstaigai (Brittian, Humhries, 2015). Tad, jeigu jaučiamas stiprus bendruomenès ar grupès palaikymas, ir asmuo tvirtai suvokia esantis vienos ar kitos subkultūros dalis, o pastaroji palaiko ir skatina prosocialų elgesị visuomenèje, tokiu atveju asmuo gali visomis savo išgalèmis stengtis patenkinti lūkesčius ir realizuoti savo socialinės grupès ar institucijos teigiamas idejjas. A. L. Thompson'as ir J. T. Siegel'as (2013), analizuodami prosocialų elgesị bei moralinius veiksmus, iškèlè hipotezę, kad tie asmenys, kurie susidūrè su aplinkinių moraliniais veiksmais, jausis laimingesni ir patys propaguos prosocialų elgesị. Kaip ir buvo manyta, tiriamieji, susidūrę su moraliniais aplinkinių veiksmais, jautèsi laimingesni, priešingai nei tie, kuriems teko susidurti su amoraliu. Be kita ko, laimingesni asmenys buvo dukart labiau linkę elgtis prosocialiai, negu tie, kurie jautė apmaudą ir liūdesị dèl amoralių aplinkinių veiksmų. Galima teigti, kad prosocialus elgesys skatina pozityvius jausmus, geras emocijas ir turi tiesioginę ịtaką moralinei elgsenai. Panašius rezultatus pateikia ir A. S. Brittian ir kt. (2013). Jie nustatè, kad negatyvi patirtis, tokia kaip institucinė ar socialinè diskriminacija, kelia grèsmę asmens prosocialiam samprotavimui, kartu ir elgesiui.

Gilinantis ị mokslininius tyrimus, kuriuose nagrinëjama vertybių ịtaka prosocialumui (Sagiv et al., 2011), matyti, kad geranoriškumo ir universalumo vertybės susijusios statistiškai teigiamai su prosocialiu žmogaus elgesiu, tuo tarpu galios vertybės - neigiamai. T. Malti, S. P. Dys'as ir A. Zuffianò'as (2015), analizuodami moralinių emocijų (pvz., gėdos, kaltės) ryši su prosocialiu elgesiu, patvirtino, kad empatija tiesiogiai susijusi su prosocialiu elgesiu. Taigi didesnis reikšmingu aplinkinių moralinis palaikymas, asmens egoizmo slopinimas turi įtakos prosocialių žmogus veiksmų raiškai. Šiuo atveju, jei universiteto bendruomenè (administracija, dėstytojai, vadovybė), besiremianti liberalaus ugdymo koncepcija, propaguotų, skleistų ir skatintų fundamentinėmis vertybėmis grịstą samprotavimą bei elgesį, tikètina, kad prosocialumas užimtų reikšmingą vietą ne tik vietinèje bendruomeneje, bet ir persiduotu $\mathfrak{i}$ kitas socialinio gyvenimo sritis. Tokie teoretikai kaip Sh. H. Schwartz ir J. A. Howard'as (1984) vertybes konceptualizavo kaip standartus ar tam tikros elgesio raiškos motyvus. Manoma, kad silpna sąsaja tarp elgesio ir vertybių dažniausiai yra dėl pernelyg abstraktaus asmens požiūrio ị vertybes. Tuo tarpu M. H. Bond'as ir V. M. Y. Chi (1997), naudodamiesi Sh. H. Schwartz (2012) geranoriškumo, universalumo ir prisitaikymo subskales, nustatè stiprų teigiamą ryši tarp prosocialaus elgesio bei 49 pilietiško elgesio tipų (aplinkinių gerbimo, tiesos sakymo, buvimo mandagiu kitiems). Neabejojama, kad tarpusavio ryšiai tarp prosocialaus elgesio ir vertybių egzistuoja (Hardy, Carlo 2005).

R. Barnett'o (1990) nuomone, aukštasis mokslas susiduria su dideliais sunkumais, iš kuriu esminis yra tas, kad fundamentalieji principai konfrontuoja su naujai suvokiamomis aukštojo mokslo koncepcijomis. Tradiciškai aukštojo mokslo pamatas sudarytas iš dviejų aksiomų - epistemiologinės (objektyvios tiesos atradimo galimybė) ir sociologinès (žinių objektyvumas yra įmanomas tik per santykinę universitetų autonomiją). Tačiau R. Barnett'as (1990) akcentuoja, kad pastarujų aksiomų validumu šiuo laiku yra stipriai abejojama. Būtent šis epistemiologinis ir sociologinis konfliktas apima tradicinių ir modernių vertybių klausimą. Tad liberalusis ugdymas atsiduria ypač problematiškoje situacijoje. Svarbu pagalvoti, ar universiteto vertybių perkainojimas, neatsigręžiant 
ị fundamentalumą, nesukelia didelès grèsmès liberalumo principui. Tad lieka atviras klausimas, kiek šiandieniniame transformacijas patiriančiame universitete lieka liberaliojo ugdymo?

Liberalaus ugdymo proceso ypatumai, lemiantys prosocialaus elgesio formavimąsi. Aukštesnio lygio (universitetinis) išsilavinimas plečia socialinius tinklus, tad keliama prielaidą, kad ilgas laiko praleidimas švietimo sistemoje yra priežastis, kodėl didesnis išsilavinusių žmonių skaičius yra labiau linkę elgtis prosocialiai. Tad kaip liberalaus ugdymo procese formuojasi prosocialus elgesys? P. M. King ir M. J. Mayhew’o (2002) teigimu, moralinị samprotavimą gali lemti daugybė veiksnių, pavyzdžiui, bendra intelektinė aukštojo mokslo įstaigos terpè, kuri skatina keistis idèjomis, iškelia perspektyvas, susijusias su socialiniais klausimais, siekia akademinių vertybių išgryninimo ir puoselejjimo bei asmeninès atsakomybès. Taip pat pagrịstai galima manyti, kad vieni socialiniai kontekstai yra efektyvesni nei kiti, skatinant moralinị samprotavimą (King, Mayhew, 2002), nes ne kiekvieną universitetą baigusi asmeni galima vadinti aukšta moraline atsakomybe ir prosocialiu elgesiu pasižyminčiu žmogumi. Tos institucijos, kuriose moraliniai aspektai bendruomenès gyvenime yra aiškūs, kur studentai yra skatinami galynètis su moralinėmis dilemomis ir ieškoti savo elgesio moralinių motyvų, labiau nei tos institucijos, kuriose tokios galimybès nesudarytos, formuoja prosocialų studentų elgesį. Šie aspektai remiasi R. Barnett'o (1990) išsakytais radikaliosios liberalaus ugdymo koncepcijos elementais, kur socialinès ir psichologinès kliūtys nedingsta savaime. Studijų procesas išlaisvina studentą keisti mąstymą ir požiūrị, o besiremiant savo santykio su pasauliu refleksija pamatyti savo galimybių potencialą.

Literatūroje aptinkama tyrimų, kurie atlikti siekiant prosocialų samprotavimą pamatuoti pasitelkiant skirtingas disciplinas (St. Pierre et al., 1990; Snodgrass, Behling, 1996), tačiau tai pavieniai tyrimai, teigia P. M. King ir M. J. Mayhew'as (2002). Prieš daugiau nei du dešimtmečius K. E. St. Pierre'is su bendraautoriais (1990) nustatė, kad apskaitos, verslo, informacinių technologijų, viešbučių administravimo, tarptautinio verslo studentai parodė žemesnius moralinio samprotavimo rezultatus nei psichologijos, matematikos ir socialinio darbo studentai (King, Mayhew, 2002). M. Adams ir Y. Zhob-McGover'io (1994) tyrimo duomenimis, kursai, kuriuose kalbama apie socialinę îvairovę ir socialinị teisingumą, formuoja moralinius sprendimus ir skatina kurti naujus elgesio modelius. Čia išryškejja R. Barnett'o (1990) pateikta konservatyvioji liberalaus ugdymo koncepcijos dedamoji, kad didelis dèmesys ugdymo procese turi būti skiriamas mokymo turiniui, kuris kaip įmanoma mažiau ribotų studento saviraišką ir suteiktų fundamentinių žinių bei laisvès priimant sprendimus, leistų vadovautis moraliniu samprotavimu. Akcentuotina, kad disciplinos su mažiau akivaizdžiomis nuorodomis ị dorinị ugdymą gali užtikrinti teigiamą požiūrị i prosocialumą. Be kita ko, studentų sprendimų prièmimas ir aktyvus mokymasis - įvardijami kaip vieni svarbiausių formuojantis jų moraliniam samprotavimui, prosocialiam elgesiui (King, Mayhew, 2002). Autoriai mano, kad galvojant apie mokymo turinị ir mokymo metodus, kurie sudaro disciplinos pagrindą, reikia suprasti, kad naudinga atlikti intervenciją, skatinančią moralinio samprotavimo raišką, nekalbant apie tokias programas, kaip etikos kursas, bendruomeniniai paslaugu projektai, pedagogika, kuri kviečia nagrinėti moralinius prieštaravimus. Pastebime, kad mokymo turinys stipriai prisideda prie esminio R. Barnett'o (1990) išsakyto liberalaus ugdymo tikslo - kritiškai mąstančio žmogaus, nes, mokslininko nuomone, kritiškas mąstymas reiškia studentų autonomijos vystymąsi ir 
galimybę kiekvienam laikytis savo vertybinių pozicijų. Šis siekis remiasi konservatyviaja liberalaus ugdymo koncepcija.

Dauguma mokslo institucijų siekia mokyti savo studentus būti gerais piliečiais, rodyti moralinio lyderio ir vertybių puoselètojo pavyzdị bei ugdyti teisingų sprendimų prièmimo ịgūdžius tuo tikslu, kad studentas galètų naudotis savo pozityvia praktika kurdamas šviesią ateiti po studijų baigimo. Tad reikia akcentuoti, kad studento gebejjimas prosocialiai elgtis nesivysto vien chronologiniu brendimu. Atvirkščiai, svarbu prisiminti, kad vystymasis vyksta aplinkoje, vadinasi, universitetas turi visas galimybes būti puiki institucija, stimuliuojančia prosocialų studentų veikimą.

Šiame straipsnyje buvo siekiama atskleisti prosocialaus elgesio formavimąsi universiteto liberalaus ugdymo procese, vadinasi apibendrintai galima pasakyti, kad minètas elgesys formuojasi ugdymo(-si) procese, kada universitete kuriama aukštojo mokslo terpè, kurioje skatinama idejjų kaitos laisvè, kur studentai turi galimybę priimti sprendimus ir patys spręsti iškilusias dilemas, t. y. : terpèje, kurioje nėra nusigręžta nuo socialinių ir humanitarinių mokslų, bei praktikuojamos ne tik profesinių žinių, bet ir moralinị samprotavimą implikuojančios disciplinos; terpejje, kurioje ugdymas(-is) vyksta per kritinio mąstymo plètotę ir sąmoningą asmens priklausymą institucijai, nes manoma, kad socialinès grupès ar įstaigos vertybes bei propaguojamą elgesị asmuo gali perimti tik jausdamasis tos institucijos dalimi. Minèti prosocialaus elgesio formavimosi aspektai remiasi liberalaus ugdymo paradigma, kuri nuo Platono laikų iki šių dienų yra gerokai pakitusi, tačiau išlaikanti savo svarbą šių dienų chaotiškame pasaulyje. Galiausiai, atsižvelgiant ị dabartinio universiteto ir viso aukštojo mokslo kompleksiškumą, svarbu išgryninti vertybes ir prioritetus, izžvelgti pozityvias ateities galimybes universitetui susiduriant su reikliais pasirinkimais ir iššūkiais. Kita vertus, žvelgiant i universitetą kaip ị kontroversišką instituciją su pozityviomis ateities vizijomis, labai svarbu atsigręžti i pradžios universitetą, jo šaknis ir prigimtį, nepamiršti liberalaus ugdymo vertès šių dienų žmogui ir visuomenei.

\section{IŠVADOS IR PERSPEKTYVOS}

Analizuojant prosocialaus elgesio formavimąsi universiteto liberalaus ugdymosi procese darytina išvada, kad prosocialus elgesys formuojasi ugdymo(-si) procese, kada universitete kuriama aukštojo mokslo terpè, kurioje dėmesys skiriamas socialiniam ugdymui, implikuojant moralini samprotavimą skatinančias disciplinas, suteikiant galimybę studentui keistis idejomis, iškeliant perspektyvas, susijusias su socialiniais klausimais, siekiant akademinių vertybių išgryninimo ir puoselèjimo bei asmeninès atsakomybès. Iš esmès prosocialaus elgesio formavimosi elementai užkoduoti R. Barnett'o (1990) liberalaus ugdymo koncepcijose, kurios negali egzistuoti skyriumi, nes per abiejų koncepcijų dedamąsias (kritinio mąstymo plètotę, laisvę priimti sprendimus, studento saviraiška, suteikiant galimybę susidoroti su moralinèmis dilemomis) aktyviai ir tikslingai formuojasi žmogaus prosocialus samprotavimas ir elgesys. Mokslinejje literatūroje pasigendama tyrimų, kurių metu būtų bandoma atskleisti, kaip prosocialumą keičia aukštasis mokslas, tad šis tyrimas, tikimasi, suteikia platesnị suvokimą ir iškelia prielaidą tolesniems tyrinëjimams, kur būtų atsižvelgiama i universiteto, kaip visuomenès kritiko ir žinių teikèjo, vaidmenį skatinant prosocialumą. 


\section{LITERATŪRA}

1. Adams, M., Zhou-Mcgovern, Y. (1994). The Sociomoral Development of Undergraduates in a "Social Diversity" Course: Developmental Theory, Research, and Instructional Applications. Paper presented at the Annual Meeting of the American Educational Research Association. New Orleans.

2. Attitude Determines your Altitude. (2013). International school of management excellence. Prieiga internetu: < http://www.isme.in/attitude-determines-your-altitude/>

3. Barnett, R. (1990). The Idea of Higher Education. New York

4. Bartlett, Y., Desteno, D. (2006). Gratitude and prosocial behaviour. Helping when it costs you. Psychological Science, 17 (4), 319-325.

5. Bond, M. H., Chi, V. M. (1997). Values and moral behaviour in mainland China. Psychologia, 40 (4), 251-264.

6. Brittian, A. S., Humphries, M. L. (2015). Prosocial behavior during adolescence. In: James D. Wright, International Encyclopedia of the Social \& Behavioral Sciences (2nd Ed.). Oxford.

7. Brittian, A. S., O'Donnell, M., Knight, G. P. et al. (2013). Associations between adolescents' perceived discrimination and prosocial tendencies: The mediating role of Mexican American values. Journal of Youth and Adolescence, 42, 328-341. doi: 10.1007/s10964-012-9856-6

8. Carlo, G. (2006). Care-based and altruistically based morality. In: M. Killen, J. G. Smetana (Eds.), Handbook of Moral Development. Erlbaum, Mahwah.

9. Česnulevičienè, J. (2000). Liberalaus ugdymo samprata aukštajame moksle. Acta Paedagogica Vilnensia, 7, 280-285.

10. Dunfield, K., Kuhlmeier, V.A., O‘Connell, L., Kelly, E. (2011). Examining the diversity of prosocial behavior: Helping, sharing, and comforting in infancy. Prosocial Behavior in Early Development, 16, 227-247. doi: 10.1111/j.1532-7078.2010.00041.x

11. Eisenberg, N. (2006). Prosocial behavior. In: G. G. Bear, K. M. Minke, (Eds.), Children's Needs III: Development, Prevention, and Intervention. National Association of School Psychologists, Washington, DC. P. 313-324.

12. Hardy, S. A., Carlo, G. (2005). Religiosity and prosocial behaviours in adolescence: The mediating role of prosocial values. Journal of Moral Education, 34 (2), 231-249.

13. Horbačauskienè, J., Gudaityte, D. (2012). Liberaliojo ugdymo dimensija technologinio universiteto studijose. Santalka: Filologija, Edukologija, 20 (1), 36-49.

14. Horbačauskienè, J. (2011). Liberalusis ugdymas technologinio universiteto studijose: daktaro disertacija. Kauno technologijos universitetas.

15. Johnston, M., Krettenauer, T. (2011). Moral self and moral emotion expectancies as predictors of antiand prosocial behaviour in adolescence: A case for mediation? European Journal of Developmental Psychology, 8 (2), 228-243.

16. Jucevičienė P., Gudaitytė, D., Karenauskaite, V. ir kt. (2010). Universiteto edukaciné galia. Atsakas XXI amžiaus ǐššukiams: mokslo monografija. Kaunas: Technologija.

17. Jucevičienè, P. (2003). Aukštojo mokslo tradicija, šiuolaikiškumas ir perspektyva. Kaunas: Technologija. 
18. King, P. M., Mayhew, M. J. (2002). Moral judgement development in higher education: Insights from the Defining Issues Test. Journal of Moral Education, 31 (3), 247-270, doi: $10.1080 / 0305724022000008106$

19. Klanienė, I., Šmitienè, G. (2013). Mokinių prosocialaus elgesio skatinimas socialiai aktyvia veikla. Tiltai, $3,141-152$.

20. Lileikis, S. (2007). Jaunuoliu altruizmo ugdymas: sociokultūrinis kontekstas. Klaipèda: KU.

21. Lönnqvist, J. E., Verkasalo, M., Wichardt, P. C., Walkowitz, G. (2013). Personal values and prosocial behaviour in strategic interactions: Distinguishing value-expressive from value-ambivalent behaviours. European Journal of Social Psychology, 43, 554-569. doi:10.1002/ejsp.1976

22. Malti, T, Dys, S. P., Zuffianò, A. (2015). The moral foundations of prosocial behaviour. Encyclopedia on Early Childhood Development, 1-5. Prieiga internetu: < http://www.childencyclopedia.com/sites/default/files/textes-experts/en/4447/the-moral-foundations-of-prosocialbehaviour.pdf>

23. Martusevičienè, L. (2015). Universiteto vertybès XX a. iššūkių kontekste. Studijos šiuolaikinejje visuomeneje, 6 (1), 48-54.

24. McDougal, W. (1908). Social Psychology. London: Metheun. Prieiga internetu: <https://archive.org/stream/introductiontoso020342mbp\#page/n0/mode/2up>.

25. Paciello, M., Fida, R., Tramontana, C., Cole, E., Cerniglia, L. (2013). Moral dilemma in adolescence: The role of values, prosocial moral reasoning and moral disengagement in helping decision making. European Journal of Developmental Psychology, 10 (2), 190-205.

26. Padilla-Walker, L. M., Nelson, L. J. (2010). Parenting and adolescents' values and behaviour: The moderating role of temperament. Journal of Moral Education, 39 (4), 491-509.

27. Penner, L. A., Dovidio, J. F., Piliavin, J. A., Schroeder, D. A. (2004). Prosocial behavior: Multilevel perspectives. Annual Review of Psychology, 56, 365-392.

28. Sagiv, L., Sverdlik, N., Schwarz, N. (2011). To compete or to cooperate? Values' impact on perception and action in social dilemma games. European Journal of Social Psychology, 41, 64-77.

29. Schwartz, S. H., Howard, J. A. (1984). Internalized values as motivators of altruism. In E. Staub, D. BarTal, J. Karylowski and J. Reyowski (Eds.). Development and Maintenance of Prosocial Behavior: International Perspectives on Positive Morality. New York: Plenum. P. 229-255.

30. Silva, P. A, Stanton, W. R. (1996). From Child to Adult. The Dunedin Multidisciplinary Health and Development Study. Auckland: Oxford University Press.

31. Snodgrass, J., Behling, R. (1996). Differences in moral reasoning between college and university business majors and non-business majors. Business and Professional Ethics Journal, 15, 79-84.

32. Srivastava, P. SH. (2015). Adolescence period: Reflections through spiritual education. International Journal of Multidisciplinary Approach and Studies, 2 (1), 49-54.

33. St. Pierre, K. E., Nelson, E. S., Gabbin, A. L. (1990) A stud y of ethical development of accounting majors in relation to other business and non business disciplines. Accounting Educators' Journal, 3, 23-35. 
34. Šukys, S. Šukienė, E. (2015). Validity and reliability of the Lithuanian version of prosociaal tendencies measure-revised (PTMR). Baltic Journal of Sport and Health Sciences, 3 (98), 43-49.

35. Štuopytė, E. (2010). Savanorių mokymasis vykdant socioedukacinę veiklą nevyriausybinèse organizacijose. Socialiniai mokslai, 2 (68), 123-130.

36. Thomson, A. L., Siegel, J. T. (2013). A moral act, elevation, and prosocial behavior: Moderators of morality. Journal of Positive Psychology, 8, 50-64. doi: 5064.10.1080/17439760.2012.754926

37. Thompson, K. L., Gullone, E. (2008). Prosocial and antisocial behaviors in adolescents: An investigation into associations with attachment and empathy. Anthrozoös, 21 (2), 123-137.

38. Twenge, J. M., Baumeister, R. F., DeWall, C. N., Ciarocco, N. J., Bartels, J. M. (2007). Social exclusion decreases prosocial behavior. Journal of Personality and Social Psychology, 92 (1), 56-66.

39. Veenstra, R. (2006). The development of Dr. Jekyll and Mr. Hyde: Prosocial and antisocial behavior in adolescence. In D. Fetchenhauer, A. Flache, A. Buunk, S. Lindenberg (Eds.), Solidarity and Prosocial Behavior: An Integration of Sociological and Psychological Perspectives. New York, NY: Springer, 93105.

40. Žukauskienė, R., Malinauskienė, O. (2009). Asmenybės bruožų ir vertybių poveikis paauglių prosocialiai orientacijai. Socialinis Darbas, 8, 97-107.

\section{FORMATION OF PROSOCIAL BEHAVIOUR IN THE PROCESS OF UNIVERSITY LIBERAL EDUCATION}

\section{Enrika Kromerova}

Lithuanian Sports University, Kaunas, Lithuania

\section{ABSTRACT}

Research background. Today prosociality is an indisputably integral part of the prosperity of society. Analysing the complex and sophisticated issues of lifelong learning of a person, a holistic and high conceptual level theory of education is needed, which is based not only on the one-fold examination of the phenomenon of education, but also on a system of philosophy-based educational paradigms. Thus, liberal education is regarded as one of the essential and fundamental opportunities for the realization of higher education, thinking about the future of society. The above-mentioned aspects make the problematic question possible to be raised: how is prosocial behaviour formed in the liberal education process at university? The article analyses the concept and essence of prosocial behaviour and examines the value basis of liberal education in order to reveal the possibilities of liberal education that determines prosocial behaviour at university. R. Barnett's (1990) liberal educational approach and conservative and radical concepts are used in this research.

The aim was to reveal the formation of prosocial behaviour in the process of university liberal education.

Method. The method of scientific literature analysis was used in the research in order to reveal the formation of prosocial behaviour during the liberal education process at university.

Results and conclusions. The elements of the formation of prosocial behaviour are encoded in R. Barnett's (1990) liberal educational concepts that cannot exist separately, because the components of both 
concepts (development of critical thinking, freedom to make decisions, student self-expression, the ability to deal with moral dilemmas) actively and purposefully formulate human prosocial reasoning and behaviour .

Keywords: liberal education, university, prosocial behaviour, higher education. 